\title{
Prostaglandin E Positively Modulates Endothelial Progenitor Cell Homeostasis: An Advanced Treatment Modality for Autologous Cell Therapy
}

\author{
Tanja Herrler Simon F. Leicht Stephan Huber Patrick C. Hermann \\ Theresa M. Schwarz Reinhard Kopp Christopher Heeschen \\ Department of Surgery, Experimental Medicine, Ludwig Maximilian University, Munich, Germany
}

\section{Key Words}

Stem cells · Progenitor cells • Cardiovascular disease •

Vasculogenesis $\cdot$ Ischemia $\cdot$ Cell therapy

\begin{abstract}
Aims: The mobilization of endothelial progenitor cells (EPC) and their functioning in postnatal neovascularization are tightly regulated. To identify new modulators of EPC homeostasis, we screened biologically active prostaglandin E compounds for their effects on EPC production, trafficking and function. Methods and Results: We found that EPC are a rich source for prostaglandin $E_{2}\left(P G E_{2}\right)$, stimulating their number and function in an auto- and paracrine manner. In vivo blockade of $\mathrm{PGE}_{2}$ production by selective cyclooxygenase- 2 inhibition virtually abrogated ischemia-induced EPC mobilization demonstrating its crucial role in EPC homeostasis following tissue ischemia. Conversely, ex vivo treatment of isolated EPC with the clinically approved $\mathrm{PGE}_{1}$ analogue alprostadil enhanced EPC number and function. These effects were mediated by increased expression of the chemokine receptor CXCR4 and were dependent on nitric oxide synthase activity. Most importantly, ex vivo PGE 1 pretreatment of isolated EPC significantly enhanced their neovascularization capacity in a murine model of hind limb ischemia as assessed by laser Doppler analysis, exercise stress test and immunohistochemistry. Conclusions: The conserved role for PGE in the regulation of EPC homeostasis suggests that
\end{abstract}

ex vivo modulation of the prostaglandin pathway in isolated progenitor cells may represent a novel and safe strategy to facilitate cell-based therapies. Copyright $\odot 2009$ S. Karger AG, Basel

\section{Introduction}

A major goal in cardiovascular regenerative medicine is to halt or even reverse tissue damage by enhanced neovascularization and regeneration. Endothelial progenitor cells (EPC) play a crucial role in the functional balance of the vascular system as vascular function and neovascularization strongly depend on EPC number and functional capacity $[1,2]$. Since we have recently shown that progenitor cells isolated from patients with cardiovascular risk factors display a reduced neovascularization capacity in vivo, novel strategies to enhance the functional activity of autologous progenitor cells are clearly warranted $[2,3]$. While several uncontrolled studies showed promising results for the intracoronary infusion of adult stem and progenitor cells, more recent findings from controlled studies showed mixed results with respect to efficacy [4-7]. The inconclusive results from the 2 most recent randomized studies investigating the effect of treatment with bone marrow cells in patients following myocardial infarction $[6,7]$ may be explained by methodological differences. However, considering

\section{KARGER}

Fax +4161306 1234 E-Mail karger@karger.ch www.karger.com
(ㄷ) 2009 S. Karger AG, Basel

$1018-1172 / 09 / 0464-0333 \$ 26.00 / 0$

Accessible online at:

www.karger.com/jvr
Dr. Christopher Heeschen, Department of Surgery

Experimental Medicine, Ludwig Maximilian University

Marchioninistrasse 15, DE-80333 Munich (Germany)

Tel. +49 897095 6431, Fax +49 897095 3440,

E-Mail christopher.heeschen@med.uni-muenchen.de 
that vascular disease often involves reduced numbers and/or function of progenitor cells, the results also strongly suggest that treatment effects of cell therapy using plain patient-derived autologous stem and progenitor cells results in treatment effects that are not as strong as hoped for. Importantly, results from experimental studies using mostly healthy cells in a young and healthy environment may have been misleading in this respect.

As we evaluated potential new candidates for ex vivo pretreatment of isolated autologous progenitor cells, prostaglandin $\mathrm{E}$ (PGE) captured our attention as a potent stimulator of endothelial progenitor cell number and function. Endogenous $\mathrm{PGE}_{2}$ represents one of the major products of cyclooxygenase and has similar effects to the clinically approved analogue alprostadil via signaling through EP1, EP2, EP3 and EP4 receptors $[8,9]$. In the context of angiogenesis, EP2 and EP4 appear to be of particular importance. Both receptors are $\mathrm{G}_{s}$ coupled and increase intracellular cAMP formation in response to ligand binding, but they exert diverse downstream effects. While EP2 activation is known to enhance endothelial cell motility and survival via the Akt pathway [10], EP4 activation leads to upregulation of VEGF, endothelial NO synthase (eNOS) and CXCR4 receptor expression via the PI3K and ERK 1/2 signalling pathways. It thus promotes cell migration, angiogenesis and homing [11-14].

Here, we demonstrate that $\mathrm{PGE}_{2}$ plays an essential role in EPC homeostasis. EPC depend critically on cyclooxygenase-2 (COX-2) activity, as EPC numbers were significantly reduced by widely used COX-2 inhibitors. Most importantly, we demonstrate for the first time the efficacy of these cells in the restitution of vasculature and function following ischemia. Regarding the translation of these findings into a clinical application, we provide evidence that ex vivo stimulation of the prostaglandin pathway in prospectively isolated EPC represents a novel and safe strategy to enhance the functional activity of autologous progenitor cells in patients with diverse vascular diseases.

\section{Subjects and Methods}

Recruitment of Study Patients and Healthy Control Subjects Peripheral blood was obtained from individuals after informed consent had been given. Five male nondiabetics with angiographically documented stable coronary heart disease (mean age $64.0 \pm 4.5$ years) were enrolled alongside 3 male age-matched diabetics without clinical evidence of coronary heart disease (mean age $43.7 \pm 21.5$, known diabetes for $11.0 \pm 9.5$ years, HbAlc $8.5 \pm 1.4 \%)$. Twenty healthy male control subjects were also enrolled (mean age $28.4 \pm 6.2$ years).
Human Progenitor Cell Isolation and Pretreatment

Circulating endothelial progenitor cells were isolated from peripheral blood by density-gradient centrifugation with Ficoll, as previously described $[7,12]$. Briefly, total mononuclear cells $(8 \times$ $10^{6}$ cells $/ \mathrm{ml}$ medium, cell density $2.5 \times 10^{6}$ cells $/ \mathrm{cm}^{2}$ ) were plated on plastic culture dishes coated with human fibronectin (Sigma, Munich, Germany) and maintained in endothelial basal medium supplemented with EGM SingleQuots (EBM, CellSystems, St. Katharinen, Germany), VEGF (100 ng/ml) and 20\% fetal calf serum (Biochrom, Berlin, Germany) for 96 h. Isolated cells were pretreated by exposure to the clinically approved $\mathrm{PGE}_{1}$ analogue alprostadil ( $5 \mathrm{ng} / \mathrm{ml}$; Sigma), the long-lasting derivate $\mathrm{dmPGE}_{2}$ ( $5 \mathrm{ng} / \mathrm{ml}$; Cayman Chemical, Ann Arbor, Mich., USA), or one of the COX inhibitors aspirin (100 $\mu \mathrm{M}$; Sigma), ibuprofen $(100 \mu \mathrm{M}$; Sigma) and parecoxib (100 $\mu \mathrm{M}$; Dynastat ${ }^{\mathrm{TM}}$, Pfizer Inc., New York, N.Y., USA), during the final $24 \mathrm{~h}$ at $37^{\circ} \mathrm{C}$ with $5 \% \mathrm{CO}_{2}$.

Moreover, we also isolated endothelial colony-forming cells as an alternative source of progenitor cells, as previously described [15]. Briefly, mononuclear cells were cultured with complete EGM-2 medium in 6-well tissue culture plates precoated with type 1 rat tail collagen (BD Biosciences, Bedford, Mass., USA). After $24 \mathrm{~h}$, nonadherent cells and debris were removed. For the following 7 days, medium was changed daily, then every other day until the colonies appeared. Colonies were picked and further expanded for the experiments.

\section{$P G E_{2}$ Levels in Supernatant}

After $24 \mathrm{~h}$ pretreatment, we determined $\mathrm{PGE}_{2}$ levels in concentrated EPC-conditioned medium by ELISA according to the manufacturer's instructions (R\&D Systems, Wiesbaden, Germany).

\section{Cell Cycle Analysis of Isolated Progenitor Cells}

To investigate proliferation and apoptosis, cells were analyzed using a BrdU Flow Kit (eBioscience, San Diego, Calif., USA). Cells were pulsed with BrdU for $2 \mathrm{~h}$, and afterwards full cell cycle analysis was performed using BrdU and 7AAD from the kit. Experiments were carried out according to the manufacturer's instructions.

eNOS mRNA Expression

Total RNA from EPC was isolated by using the RNeasy kit (Qiagen, Hilden, Germany). RNA from HUVEC served as positive controls. Quantification of eNOS mRNA was performed by semiquantitative RT-PCR of $100 \mathrm{ng}$ RNA and the previously described primers [16].

Assessment of the Migratory Capacity of Progenitor Cells

A total of $5 \times 10^{5}$ cells was resuspended in $250 \mu \mathrm{l} \mathrm{X-Vivo} \mathrm{and}$ placed in the upper chamber of a modified Boyden chamber filled with Matrigel ${ }^{\mathrm{TM}}$ (BioCoat ${ }^{\circledR}$ invasion assay, $8 \mu \mathrm{m}$ pore size; BD Biosciences). For mechanistic analyses the eNOS inhibitor $\mathrm{N}^{\mathrm{G}}$ nitro-L-arginine-methyl-ester (LNMA; $1 \mathrm{mM}$; Sigma Aldrich, St. Louis, Mo., USA) or CXCR4 neutralizing antibodies $(20 \mu \mathrm{g} / \mathrm{ml}$; R\&D Systems, Minneapolis, Minn., USA) were added. The upper chamber was placed in a 24 -well culture dish containing $500 \mu \mathrm{l}$ EBM supplemented with $100 \mathrm{ng} / \mathrm{ml}$ stromal-derived factor-1 (a specific CXCR4 ligand). After $24 \mathrm{~h}$ of incubation at $37^{\circ} \mathrm{C}$, transmigrated cells were counted by 2 independent investigators. Samples were analyzed in duplicate. 


\section{Flow Cytometry}

Surface expression of endothelial markers and CXCR4 on human EPC was assessed by standard flow cytometry. Cells were incubated for 15 min with Flebogamma (Grifols, Langen, Germany) to prevent unspecific binding of antibodies. Then, cells were stained using antibodies against CD31 (eBioscience) and CXCR4 (R\&D Systems, Minneapolis, Minn., USA). We used flow cytometry analysis to identify murine EPC that stained double positive with FITC-conjugated antibodies against mouse CD34 and PE-conjugated antibodies against Flk-1 (eBioscience). Staining was performed in the presence of saturating concentrations of rat monoclonal unconjugated antibodies against $\mathrm{Fc}$ receptors (anti-CD16/32; eBioscience) to prevent nonspecific binding. Isotype-identical antibodies served as controls $\left(\mathrm{IgG}_{1}-\mathrm{PE}\right.$ and $\mathrm{IgG}_{2 \mathrm{a}}$ FITC; eBioscience). Each analysis included 100,000 gated events. All samples were analyzed using FACSCalibur and data were analyzed with CELLQuest Pro software (both from Becton Dickinson, Franklin Lakes, N.J., USA).

\section{Animal Models}

All animal experiments were conducted in accordance with institutional guidelines and were approved by the administrative panel on laboratory animal care of the government of Upper Bavaria, Germany. 8- to 10-week-old female BALB/c WT mice and athymic NMRI nu/nu mice (both from Charles River, Sulzfeld, Germany) weighing 18-22 g were used in the experiments. For in vivo stimulation, $\mathrm{BALB} / \mathrm{c}$ mice with or without hind limb ischemia were treated with $0.9 \% \mathrm{NaCl}, \mathrm{PGE}_{2}$ analogue $\mathrm{dmPGE}_{2} 10$ $\mu \mathrm{g} / \mathrm{kg} /$ day, or parecoxib $25 \mathrm{mg} / \mathrm{kg} /$ day intraperitoneally for 4 days. NMRI nu/nu mice were subjected to hind limb ischemia $24 \mathrm{~h}$ before intravenous administration of pretreated human progenitor cells ( $10^{5}$ cells per mouse).

\section{Hind Limb Ischemia Model}

The in vivo neovascularization capacity of progenitor cells was investigated in a murine model of hind limb ischemia. The proximal portion of the right femoral artery, including the superficial and the deep branches, were irreversibly disrupted by means of electrical coagulation. The overlying skin was closed using surgical staples.

\section{Limb Perfusion Measurements}

Two weeks after injection of the progenitor cells, we consecutively determined the blood flow of the ischemic (right) and nonischemic (left) limb using the O2C laser Doppler blood flow analyzer and the micro probe LFM-2 ( $2 \mathrm{~mm}$ tissue penetration; both Lea Medizintechnik, Giessen, Germany). Prior to analysis, mice were placed on a heating pad at $37^{\circ} \mathrm{C}$ to minimize variations in temperature. Relative perfusion was calculated as the ratio of blood flow in the ischemic and the nonischemic limb.

\section{Determination of the Exercise Capacity}

To assess alterations in the exercise capacity after progenitor cell infusion following hind limb ischemia, we performed swimming tests using a countercurrent swimming pool [23]. The current in the pool was maintained at a flow rate of $1.0 \mathrm{~m} / \mathrm{s}$ by means of 5 electric water pumps. The water temperature was maintained at $34^{\circ} \mathrm{C}$ by a water heater and thermostat. To accustom the mice to the swimming experience, all mice were subjected to daily swimming training for 7 consecutive days after which only mice with a stable maximum swimming time were selected for the study. The maximum swimming time was defined as the time to fail to remain above the surface of the water for more than $5 \mathrm{sec}$ onds.

\section{Histological Analysis}

Capillary density was determined in $8-\mu \mathrm{m}$ frozen sections of the adductor and semimembraneous muscles. Endothelial cells were stained for CD31 (PE-labeled; eBioscience). Myocyte membranes were stained using an antibody to laminin (rabbit; Acris Antibodies GmbH, Hiddenhausen, Germany) followed by antirabbit-Alexa 488 (Molecular Probes, Portland, Oreg., USA). Conductance vessels in the adductor and semimembraneous muscles were identified by size $(>20 \mu \mathrm{m})$ and staining of smooth muscle actin, using a Cy3-labeled mouse monoclonal antibody (Sigma). Small $(<50 \mu \mathrm{m})$, medium $(50-100 \mu \mathrm{m})$ and large vessels $(>100$ $\mu \mathrm{m})$ were counted separately. Injected human progenitor cells were identified by double staining for human HLA-ABC (APClabeled; eBioscience) and CD31 (FITC-labeled; eBioscience). Nuclei were stained with Dapi (Vector Lab, Burlingame, Calif., USA). Images were obtained by confocal microscopy (LSM 510 Meta; Zeiss, Germany).

\section{Isolation of Murine Spleen EPC}

Spleen progenitor cells were identified using the early EPC assay, as published previously [18]. Briefly, spleens were placed in $2 \mathrm{ml}$ of RPMI medium 1640 (Invitrogen, Carlsbad, Calif., USA) at $4{ }^{\circ} \mathrm{C}$. The tissue was minced and immediately homogenized and processed. Mononuclear cells were isolated by density gradient centrifugation using Ficoll (PAN Biotech, Aidenbach, Germany), washed and plated on fibronectin coated culture dishes. After 4 days of EPC culture cell numbers were assessed by 2 independent investigators.

\section{Statistical Analysis}

If not stated otherwise, results for continuous variables are means \pm standard deviations and are illustrated as box plots (median, interquartile range, total range and outlier). Post hoc range tests and pairwise multiple comparisons were performed with the t test (2-sided) with Bonferroni adjustment. Comparison of categorical variables was generated by the Pearson $\chi^{2}$ test. $\mathrm{p}<0.05$ was considered statistically significant. All analyses were performed with SPSS 12.0 (SPSS Inc., Chicago, Ill., USA).

\section{Results}

\section{$\mathrm{PGE}_{2}$ is an Endogenous Modulator of EPC Homeostasis}

To define the role of $\mathrm{PGE}_{2}$ in EPC homeostasis, we determined $\mathrm{PGE}_{2}$ levels in concentrated EPC-conditioned medium by ELISA (fig. 1a). Treatment of isolated human EPC with clinically relevant doses of different COX inhibitors resulted in a marked reduction in $\mathrm{PGE}_{2}$ levels. While aspirin, which primarily, but irreversibly, inhibits COX-1 demonstrated only a trend towards reduced $\mathrm{PGE}_{2}$ levels, ibuprofen, a combined inhibitor of COX-1 and 

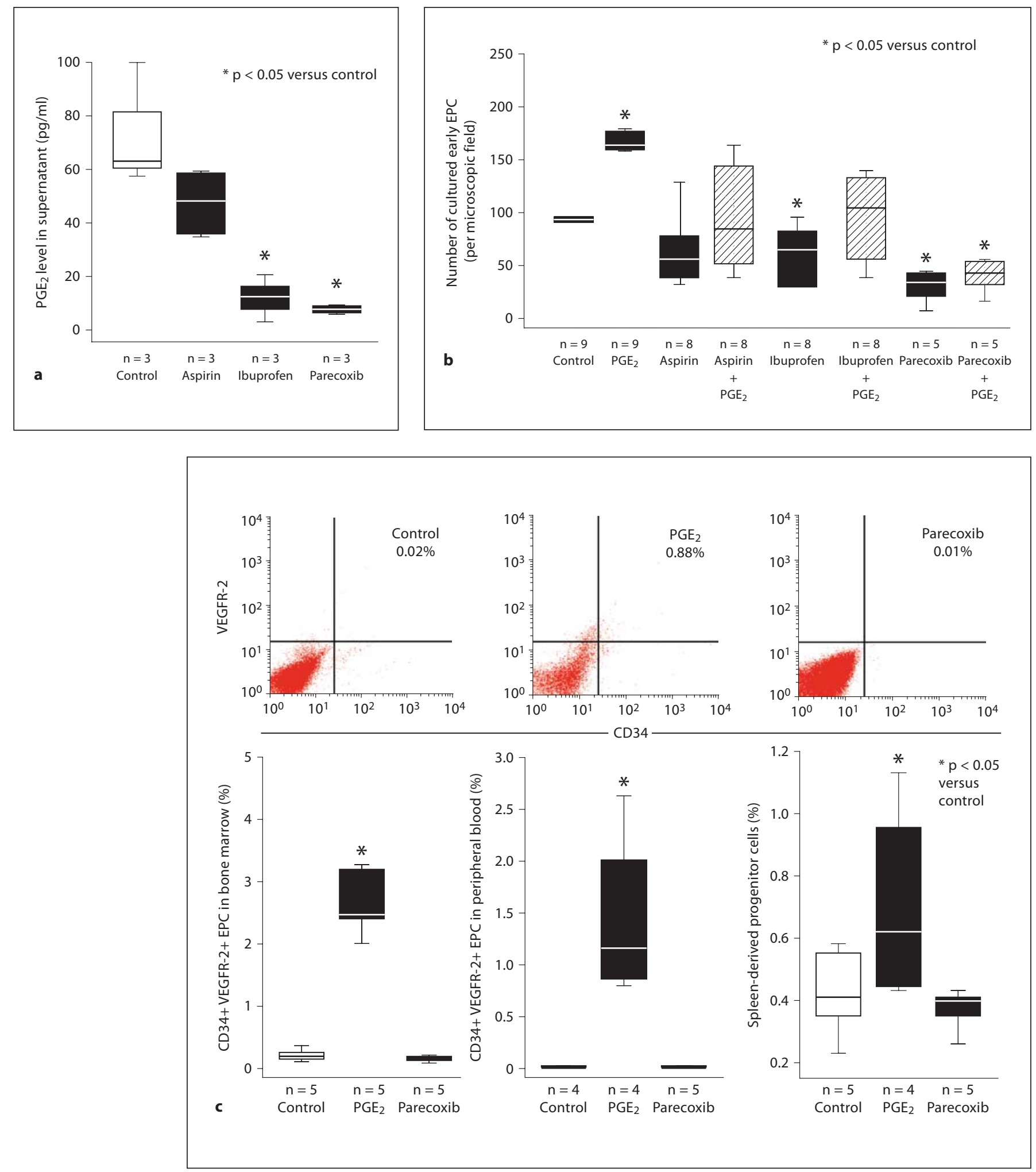
COX-2, as well as the selective COX-2 inhibitor parecoxib significantly reduced PGE levels. Consistently, the number of cultured EPC was slightly, but not significantly, reduced by aspirin (fig. 1b). In contrast, ibuprofen treatment resulted in an almost $50 \%$ reduction of EPC numbers, an effect that could be rescued by exogenous administration of $\mathrm{PGE}_{2}$. The selective COX-2 inhibitor parecoxib reduced EPC numbers to an even greater extent $(-70 \%)$. Notably, this effect could not be reversed by exogenous administration of $\mathrm{PGE}_{2}$.
Consistently, in vivo administration of $\mathrm{PGE}_{2}$ in nonischemic mice resulted in a significant increase in the number of EPC in the bone marrow, spleen, and peripheral circulation (fig. 1c), whereas COX-2 inhibition did not alter EPC levels. To investigate the effect of COX- 2 inhibition on ischemia-induced EPC mobilization, animals were subjected to hind limb ischemia. Strikingly, the ischemia-induced mobilization of EPC was virtually abrogated by selective COX-2 inhibition (fig. 1d). These data demonstrate a crucial role for $\mathrm{PGE}_{2}$ in EPC homeostasis.

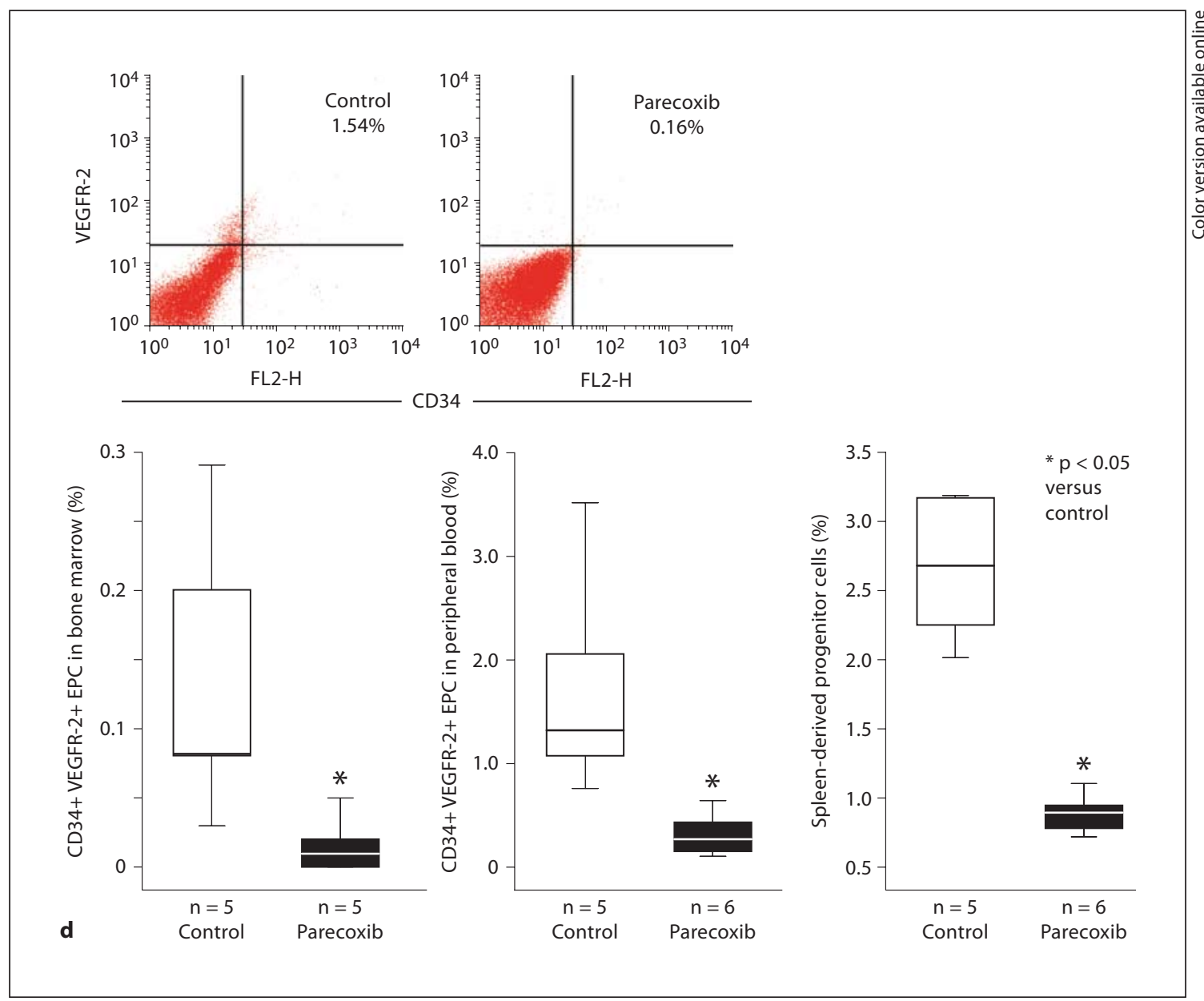

Fig. 1. Role of endogenous PGE production on progenitor cell homeostasis. a PGE production in progenitor cell-conditioned medium was assessed by ELISA. Human EPC were treated for $24 \mathrm{~h}$ with either vehicle, $5 \mathrm{ng} / \mathrm{ml} \mathrm{PGE}_{2}$, or one of the following COX inhibitors at a concentration of $100 \mu \mathrm{M}$. Aspirin blocks COX-1 irreversibly. Ibuprofen is an inhibitor of COX-1 and COX-2 and parecoxib selectively inhibits COX-2. $\mathbf{b}$ The effect of COX inhibition on progenitor cell numbers was investigated using the early EPC assay. Human cells were exposed to $\mathrm{PGE}_{2}$ and/or the COX inhibitors during the final 24 h. c The role of $\mathrm{PGE}_{2}$ on progenitor cell homeostasis was investigated in vivo using nonischemic BALB/c mice. Mice intraperitoneally received $0.9 \% \mathrm{NaCl}, \mathrm{PGE}_{2}$ analogue $\mathrm{dmPGE}_{2}$, or parecoxib. After 4 days of treatment, progenitor cells in bone marrow and peripheral blood were identified by flow cytometry following staining for CD34 and VEGFR-2. Double positive cells were judged as endothelial progenitor cells. Spleen-derived EPC cells were identified using the early EPC assay. $\mathbf{d}$ The role of endogenous $\mathrm{PGE}_{2}$ in ischemia-induced progenitor cell mobilization was investigated using a murine model of hind limb ischemia. Treatment was started on the day of hind limb ischemia. 

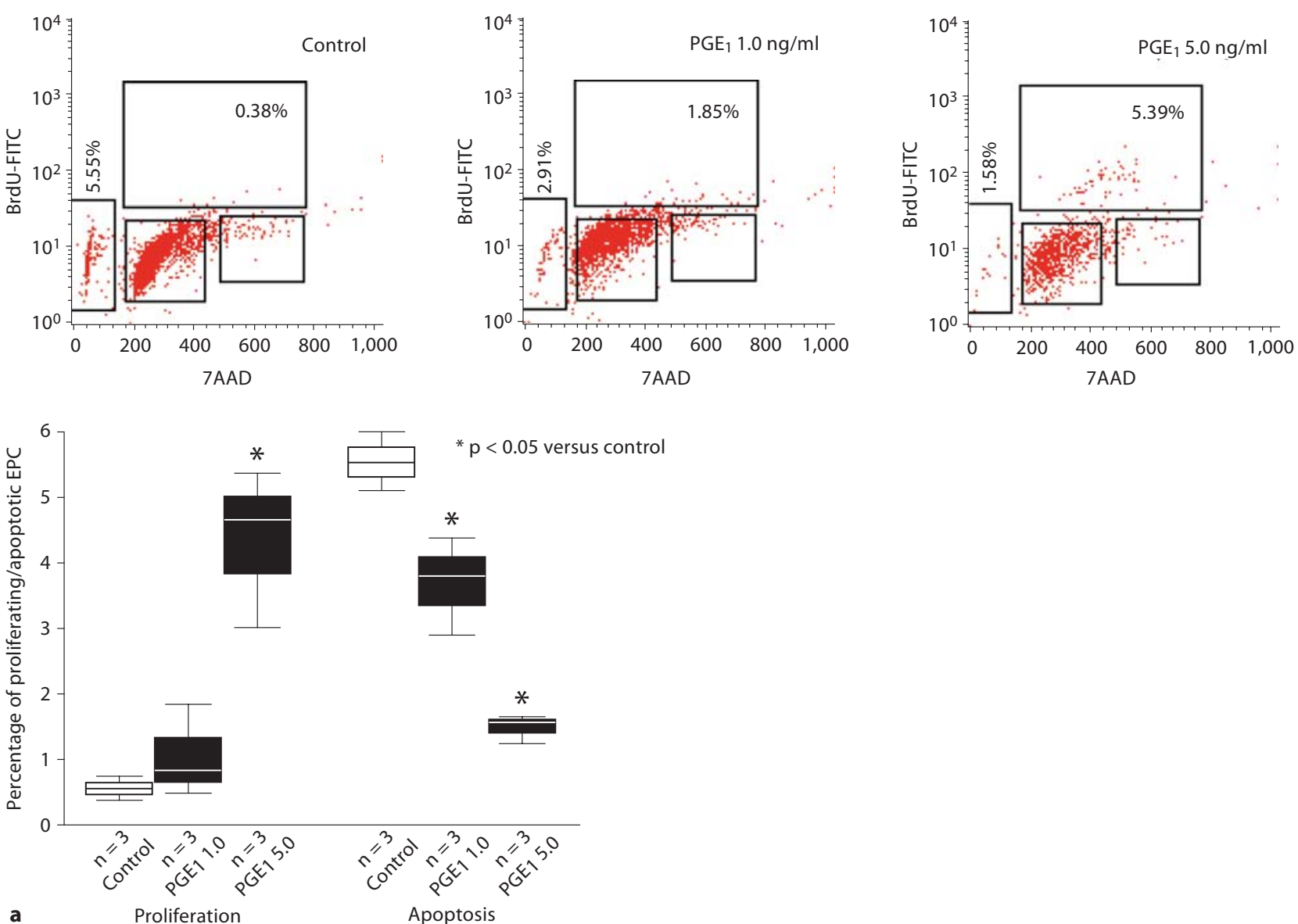

Fig. 2. Increase in cell proliferation, expression of CD31 and CXCR4 surface markers. a Cell proliferation and apoptosis were assessed by flow cytometry using BrdU pulsing and 7AAD staining (upper panel). The $\mathrm{PGE}_{1}$ analogue alprostadil was used for cell stimulation (lower left panel). Consistently, apoptosis was reduced upon pretreatment with $\mathrm{PGE}_{1}$ (lower right panel). $\mathbf{b} \mathrm{PGE}_{1}$ treatment resulted in increased numbers of EPC. This effect was observed both in cells from healthy controls as well as in cells derived from patients with coronary heart disease (CHD) and diabetics, respectively.

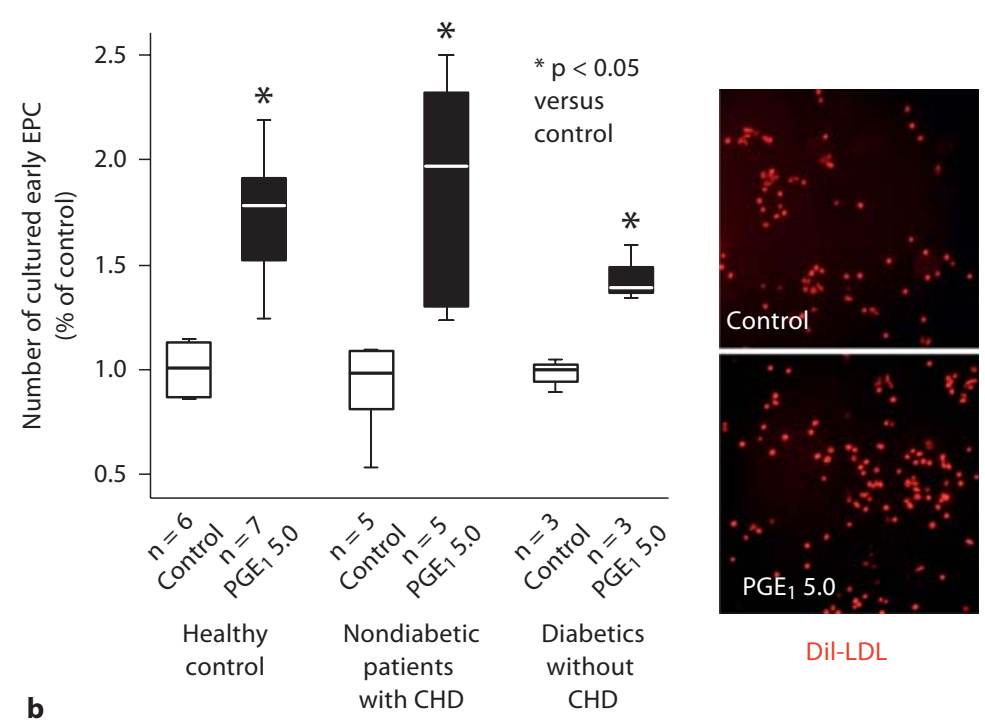



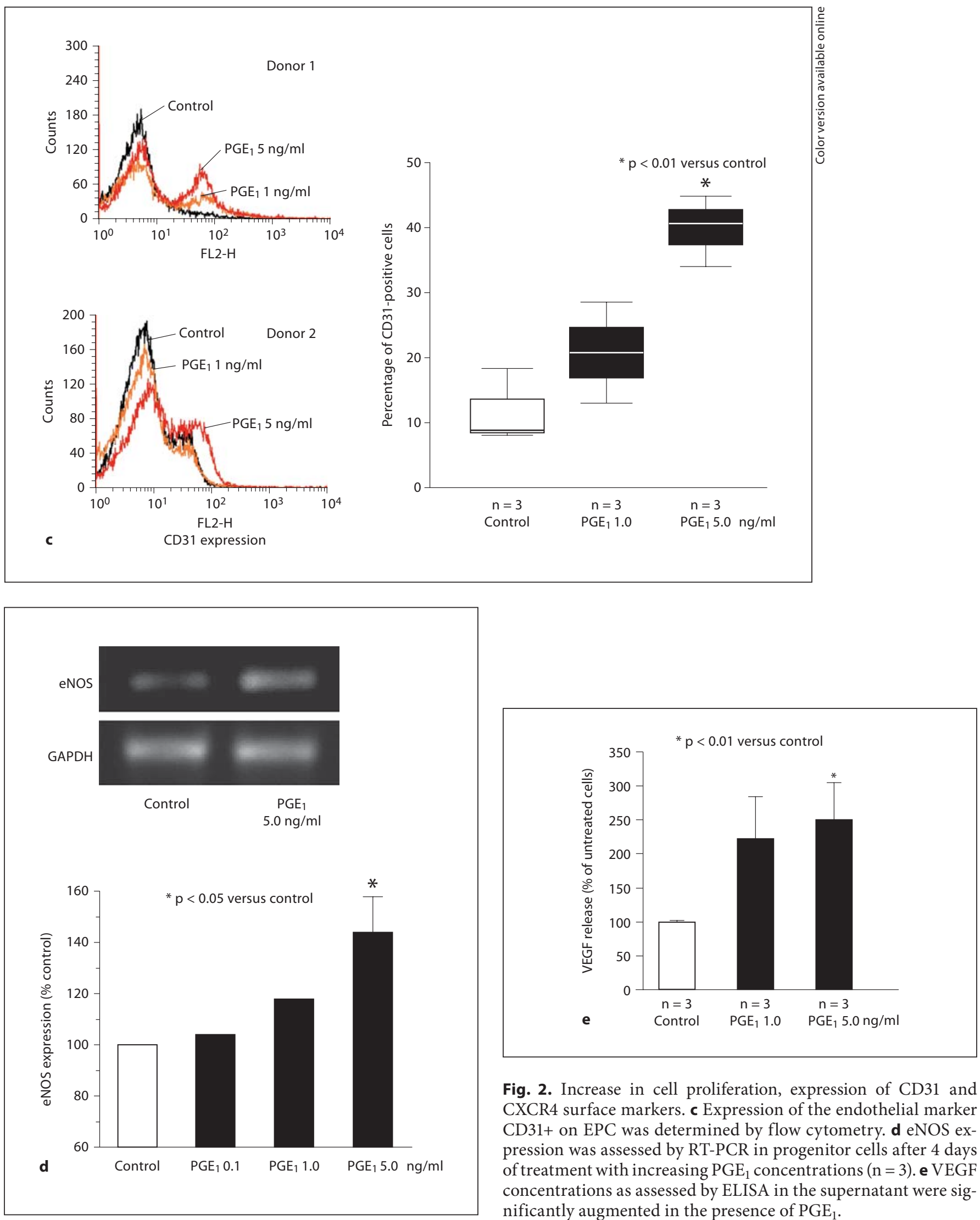

Fig. 2. Increase in cell proliferation, expression of CD31 and CXCR4 surface markers. c Expression of the endothelial marker $\mathrm{CD} 31+$ on EPC was determined by flow cytometry. d eNOS expression was assessed by RT-PCR in progenitor cells after 4 days of treatment with increasing $\mathrm{PGE}_{1}$ concentrations $(\mathrm{n}=3)$. e VEGF concentrations as assessed by ELISA in the supernatant were significantly augmented in the presence of $\mathrm{PGE}_{1}$. 
Exogenous Administration of $P G E_{1}$ Increases Yield of Early EPC

While $\mathrm{PGE}_{2}$ is the predominant endogenous form of PGE, the $\mathrm{PGE}_{1}$ analogue alprostadil has been approved for the treatment of peripheral artery disease and therefore was used for the subsequent translational experiments. In another set of experiments, we were able to demonstrate that in vivo stimulation of nonischemic mice is similarly effective with $\mathrm{PGE}_{1}$ as compared to $\mathrm{PGE}_{2}$ [change in blood borne EPC (\% of control mice) for $\mathrm{PGE}_{1}$ was $383 \pm 104 \%$ and for $\mathrm{PGE}_{2}$ it was $350 \pm 180 \%$; not significant]. Moreover, in this experimental setup, we did not find evidence for a strong proinflammatory effect during short-term treatment with either $\mathrm{PGE}_{1}$ or $\mathrm{PGE}_{2}$ [change in WBC (\% control mice) for $\mathrm{PGE}_{1}$ was $150 \pm 100 \%$ and for $\mathrm{PGE}_{2}$ it was $130 \pm 30 \%$; not significant]. Exposure of EPC to $\mathrm{PGE}_{1}$ for 4 days increased the number and proliferation of isolated EPC. While a low $\mathrm{PGE}_{1}$ dose of $1 \mathrm{ng} / \mathrm{ml}$ only slightly stimulated cell proliferation, $5 \mathrm{ng} / \mathrm{ml} \mathrm{PGE}_{1}$ caused almost $5 \%$ of the cells to proliferate compared to less than $1 \%$ in medium-treated control EPC (fig. 2a). Consistently, the number of apoptotic cells was reduced to around $1 \%$ by high-dose $\mathrm{PGE}_{1}$ treatment (fig. 2a). Consequently, the number of cultured early EPC in the $\mathrm{PGE}_{1}$ group almost doubled as compared to control (fig. 2b). This treatment effect was also evident in EPC derived from patients with coronary heart disease and diabetics.

Basal CD31 expression, a marker of endothelial differentiation, is regularly low for early EPC, consistent with their status of emerging endothelial differentiation (fig. 2c). Low-dose PGE 1 almost doubled CD31 expression as a marker of endothelial lineage, whereas $5 \mathrm{ng} / \mathrm{ml}$ yielded a 4 -fold enhancement and led to robust CD31 expression in over $40 \%$ of cells, suggesting enhanced endothelial differentiation. Moreover, ex vivo $\mathrm{PGE}_{1}$ treatment significantly increased eNOS mRNA expression (fig. 2d). We also observed a 2.5-fold increase in VEGF concentrations in EPC supernatant in the presence of high-dose $\mathrm{PGE}_{1}$ (fig. 2e). This latter set of findings emphasizes the beneficial effects of $\mathrm{PGE}_{1}$ on the functional activity of EPC by promoting their commitment to endothelial differentiation rather than stemness characteristics.

Importantly, we were able to reproduce the above data derived from EPC by using endothelial colony forming cells, which represent an EPC subpopulation with high proliferative capacity and strong regenerative capacity, through enhancing postnatal vasculogenesis [15]. Despite their more differentiated nature with strong basal expression of the endothelial markers CD31 and VEGFR2 , the stimulatory effect of $\mathrm{PGE}_{1}$ on endothelial differen- tiation was still evident (CD31 expression was 130\% of control). Moreover, $\mathrm{PGE}_{1}$ strongly induced proliferation of endothelial colony forming cells (BrdU for $2 \mathrm{~h}$ : 173\% of control; apoptosis: $9.5 \%$ of control).

\section{Enhanced Functional Activity of Progenitor Cells by $P G E_{1}$}

The CXCR4 receptor is critical for the migratory and homing capacity of circulating progenitors [19]. CXCR4 expression was significantly increased following $\mathrm{PGE}_{1}$ treatment (fig. 3a). Functionally, $\mathrm{PGE}_{1}$ resulted in a significant increase in the migratory activity (fig. 3b), while simultaneous treatment with neutralizing antibodies directed against CXCR4 reduced the effect of $\mathrm{PGE}_{1}$ on the migratory activity (fig. 3c). To define the role of eNOS in this enhanced functional activity, progenitor cells were simultaneously treated with the eNOS inhibitor LNMA, which significantly inhibited the effect of $\mathrm{PGE}_{1}$ on migration. The simultaneous treatment of progenitor cells with LNMA and CXCR4 neutralizing antibodies completely abrogated the stimulatory effect of $\mathrm{PGE}_{1}$ on cell migration. Thus, enhanced expression of eNOS and the chemokine receptor CXCR4 critically mediates the effects of $\mathrm{PGE}_{1}$ on the migratory activity of progenitor cells.

\section{Increased Neovascularization Capacity of Progenitor Cells after Pretreatment with $P G E_{1}$}

To demonstrate the clinical applicability of our findings, we investigated the neovascularization capacity of $\mathrm{PGE}_{1}$-pretreated human progenitor cells in a murine model of hind limb ischemia. The administration of progenitor cells following ex vivo $\mathrm{PGE}_{1}$ pretreatment resulted in a significantly greater enhancement of limb perfusion recovery as compared to the use of vehicle-treated progenitor cells (fig. 4a). Consistently, toe and foot necrosis in untreated animals (4/5) was markedly reduced to a single animal with toe necrosis in mice receiving $\mathrm{PGE}_{1^{-}}$ pretreated progenitor cells. In order to illustrate that the enhanced recovery of ischemic hind limb perfusion is indeed associated with improved tissue function, the physical exercise capacity of the mice was assessed using a swimming test [19]. Pretreatment of infused progenitor cells with $\mathrm{PGE}_{1}$ significantly increased the swimming time (fig. 4b).

Correspondingly, the subsequent histological analysis of the adductor muscles by hematoxylin and eosin staining showed that the ischemic muscle was much better preserved in mice receiving $\mathrm{PGE}_{1}$-pretreated progenitor cells as compared to mice receiving untreated progenitor cells (fig. 4c). The capillary density in mice receiving 


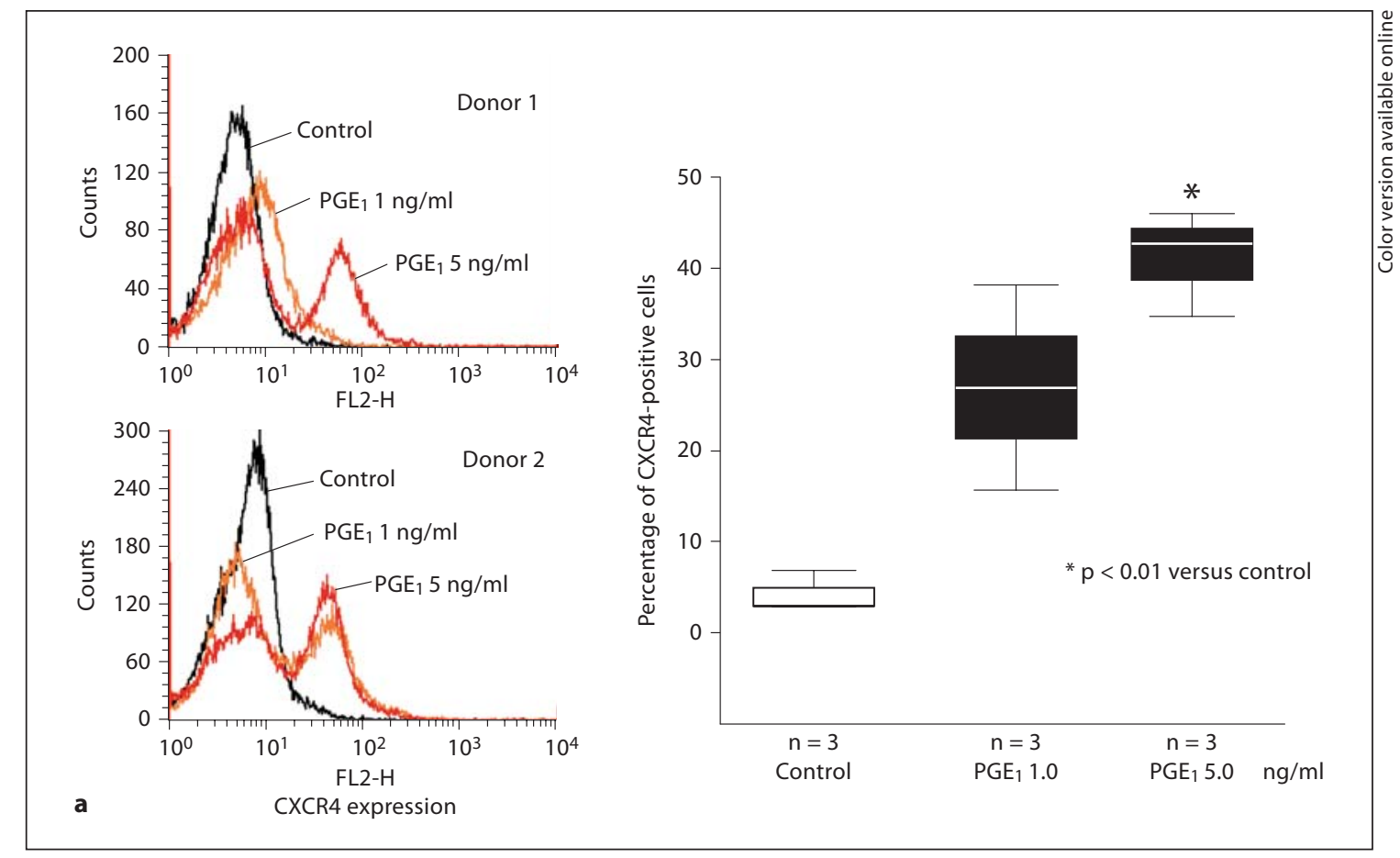

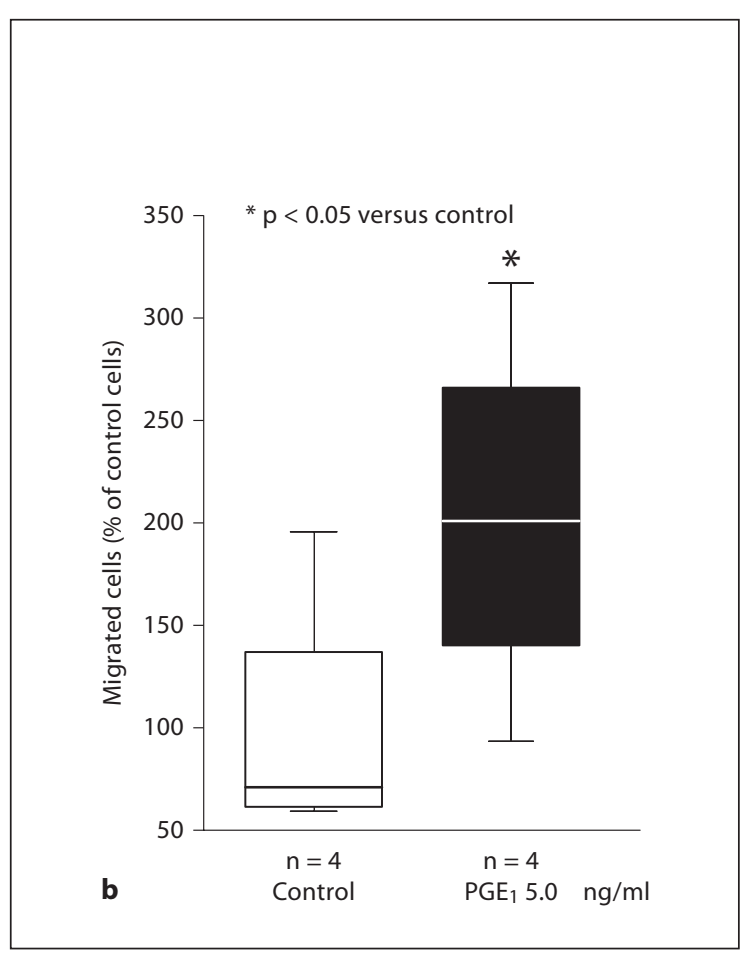

Fig. 3. Migratory capacity of progenitor cells treated with PGE. a CXCR4 expression was determined by flow cytometry and was significantly increased in EPC pretreated with $\mathrm{PGE}_{1}$. b Cell migration towards a gradient of stromal-derived factor-1 was assessed using a modified Boyden chamber assay. The numbers in-

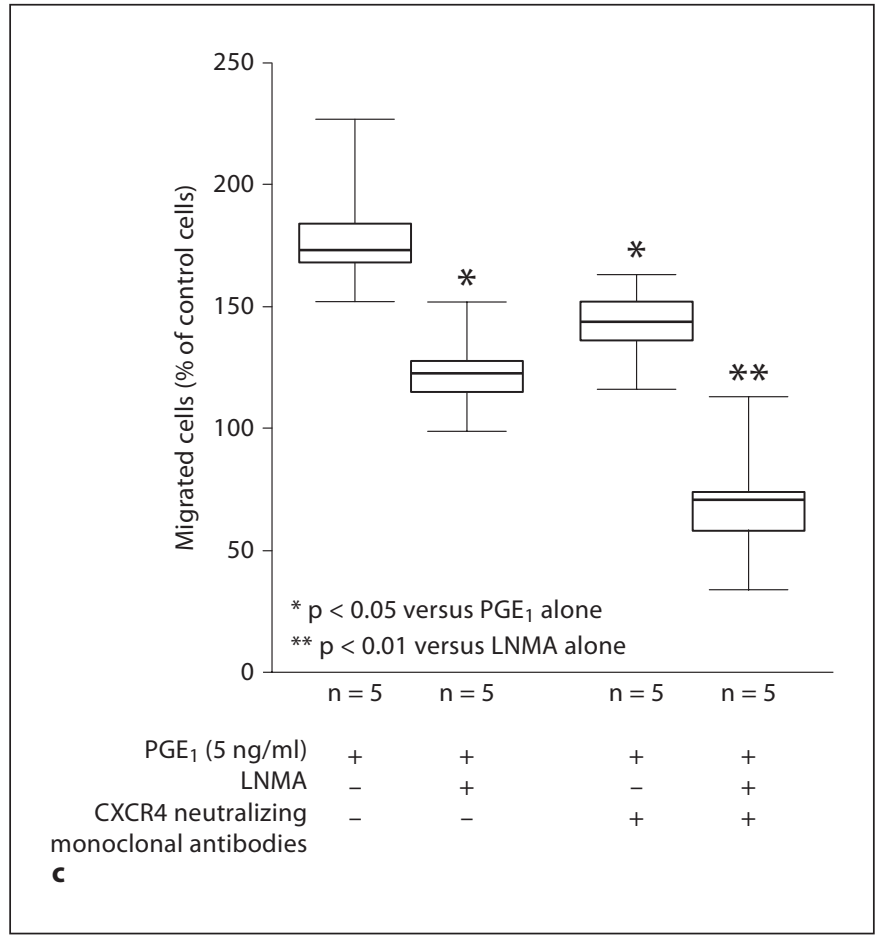

dicated are relative to control-treated cells. c The increased migratory activity of EPC pretreated with $\mathrm{PGE}_{1}$ was significantly reduced by CXCR4 neutralizing antibodies and the eNOS antagonist LNMA, respectively. Combined inhibition of eNOS and CXCR4 virtually abrogated the stimulatory effect of $\mathrm{PGE}_{1}$. 

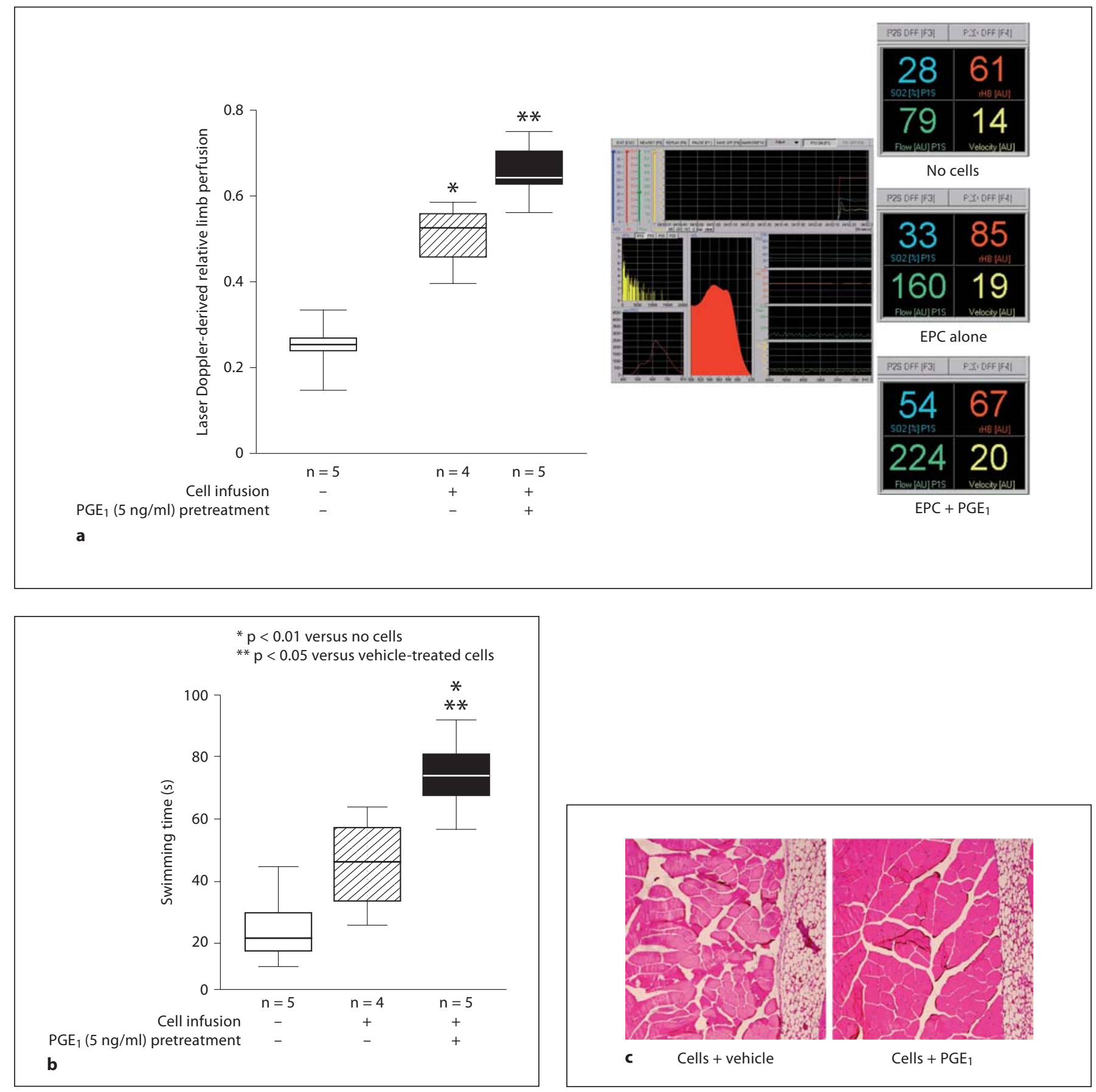

$\mathrm{PGE}_{1}$-treated progenitor cells was significantly higher as compared to vehicle-treated progenitor cells (fig. 4d). Furthermore, vascular incorporation and endothelial differentiation of injected progenitor cells was significantly enhanced by pretreatment of infused progenitor cells with $\mathrm{PGE}_{1}$ (fig. 4e).

\section{Discussion}

Based on our in vitro and in vivo findings, the present study establishes $\mathrm{PGE}_{2}$ as an endogenous regulator of EPC homeostasis. Importantly, we not only show that endogenous $\mathrm{PGE}_{2}$ modulates $\mathrm{EPC}$ numbers in vivo in re-

Herrler/Leicht/Huber/Hermann/ Schwarz/Kopp/Heeschen 
Fig. 4. Effects of PGE pretreatment on the in vivo neovascularization capacity of isolated progenitor cells. a In a murine model of unilateral hind limb ischemia, recovery of limb perfusion was assessed by laser Doppler blood flow analysis on day 14. Mice received vehicle, $10^{5}$ progenitor cells without pretreatment, or $10^{5}$ progenitor cells with $\mathrm{PGE}_{1}$ pretreatment. b Improvement of exercise capacity was evaluated by swimming time 14 days after induction of unilateral hind limb ischemia depicted by blood flow measurements (figures in the bottom left of each panel in a). c The gross histomorphology of the ischemic hind limb muscles was assessed in hematoxylin- and eosin-stained sections. d Histological analysis was performed to determine the ratio of capillaries to myocytes. e Histological analysis for the incorporation of infused EPC into blood vessels. Incorporated human cells were identified by double staining for HLA-A,B,C and CD31. Representative images are provided.
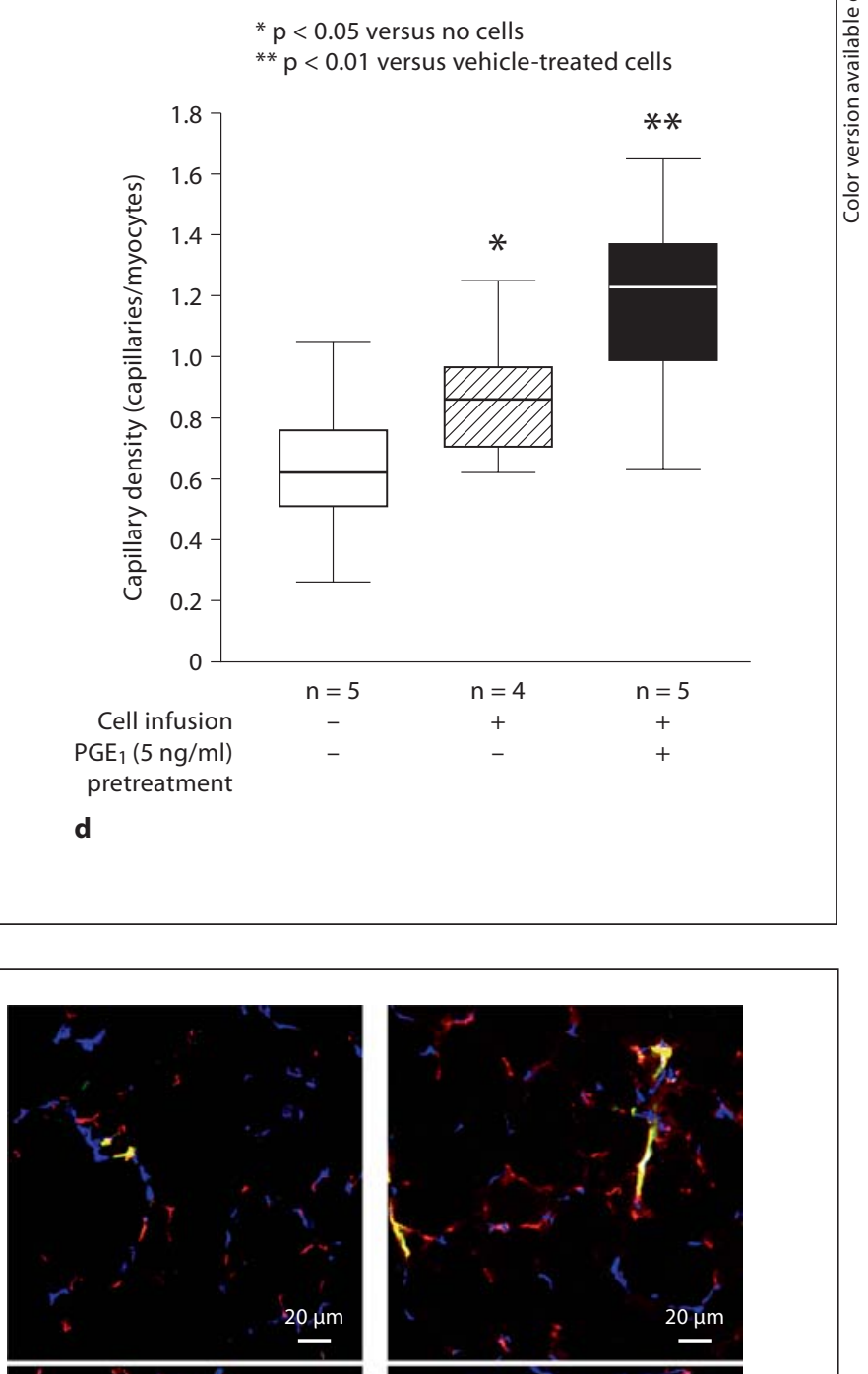

Cell infusion $\mathrm{PGE}_{1}(5 \mathrm{ng} / \mathrm{ml})$ pretreatment e
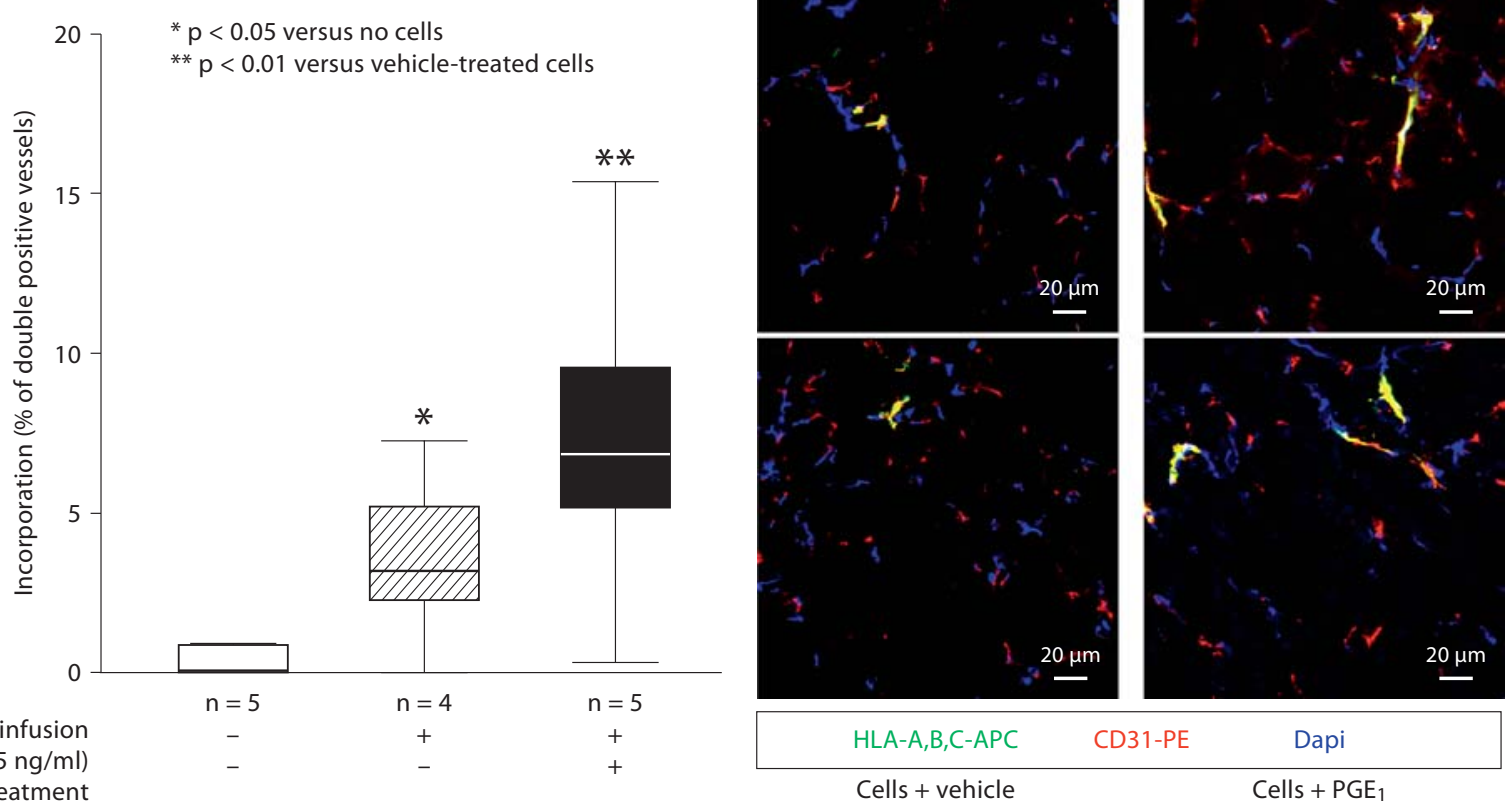
sponse to tissue ischemia, but we also provide compelling evidence for the ex vivo enhancement of patient-derived EPC function by pretreatment with the $\mathrm{PGE}_{1}$ analogue alprostadil prior to their potential use for autologous cell therapy. Although prostaglandin $\mathrm{E}$ has been primarily discussed in the context of inflammation, prostaglandins are known to be involved in multiple diverse physiological and pathological processes. Their mode of action depends on a variety of parameters (i.e. cell types involved, receptor expression profiles, and local prostaglandin concentrations) $[21,22]$. Indeed, the importance of prostaglandins in stem and progenitor cell development and function is just starting to emerge [17, 23, 24]. Recent findings by North et al. [23] uncovered a crucial role for $\mathrm{PGE}_{2}$ in hematopoietic stem cell growth and development in both embryonic and adult stem cell homeostasis.

We now demonstrate that COX-derived prostaglandins also play an important role in human EPC homeostasis. COX-1 is primarily important for the formation of the bone marrow niche [23], but COX-2 is clearly involved in the proliferation of EPC themselves. In contrast to the marginal reduction of EPC numbers following COX-1 inhibition, we found that selective COX-2 inhibition dramatically reduced EPC numbers, by about $70 \%$, suggesting that EPC possess a distinct regulatory machinery predominantly depending on COX-2. Interestingly, the reduction in EPC numbers following selective COX-2 inhibition could not be reversed by exogenous administration of $\mathrm{PGE}_{2}$. These data suggest that the stimulatory effect on EPC is not primarily a direct pharmacological stimulation of the cells by $\mathrm{PGE}_{2}$, but rather an indirect effect of $\mathrm{PGE}_{2}$ through enhanced expression of COX-2 via the positive feedback loop of the $\mathrm{PGE}_{2} \mathrm{COX}-2$ axis [25]. Since COX-2 inhibition does not affect platelet function and expression of platelet aggregation markers [26], our data may at least in part explain the diverse cardiovascular risk profiles of aspirin and COX-2 inhibitors. While aspirin reduces cardiovascular risk, more recent evidence suggests that selective and nonselective COX-2 inhibitors significantly increase cardiovascular event rates. Indeed, rather than causing an imbalance between COX-1-derived and COX-2-derived prostanoids, permanent blockade of COX-2-dependent prostaglandins and consecutively reduced EPC numbers and function may at least in part explain the cardiovascular hazard conferred by selective COX-2 inhibitors [27] and nonselective COX2 inhibitors such as ibuprofen and diclofenac [28].

Based on these data, new strategies aiming to modulate PGE signaling in isolated progenitor cells may have important clinical value to enhance the efficacy of autologous cell therapy. Prior studies have documented that $\mathrm{PGE}_{2}$ inhibits blood cell maturation in the mouse $[29,30]$ and cell cycle stimulation in CFU-S8 progenitors [31]. Gensch et al. [32] recently showed a stimulatory effect for systemic $\mathrm{PGE}_{1}$ administration on EPC mobilization and subsequent neovascularization, effects exclusively in a nonischemic murine model of inflammationinduced neovascularization, while $\mathrm{PGI}_{2}$ did not show any modulatory effect in the utilized system. However, data proving the in vivo relevance of PGE optimized human EPC in the regeneration of ischemic tissue are still lacking. Therefore, to determine the principles of functional activity of short-lived PGE and to prove its beneficial effect on human EPC, we have used the long-lasting $\mathrm{PGE}_{2}$ derivate $\mathrm{dmPGE}_{2}$ for our in vitro and in vivo studies [23]. However, for the translation of our findings to clinically applicable autologous cell therapy, we sought a safe and approved drug with $\mathrm{PGE}_{2}$-like characteristics. Considering the PGE receptor binding properties of the $\mathrm{PGE}_{1}$ analogue alprostadil, this drug indeed appeared to be the ideal candidate for our subsequent experiments. Intriguingly, in vitro pretreatment of human EPC with alprostadil markedly enhanced the culture yield and functional in vivo activity. These findings were independent of whether EPC were derived from healthy donors or from patients with coronary heart disease and diabetes, respectively. Considering the short half-life of $\mathrm{PGE}_{1}$ (5-10 $\mathrm{min}$ ) and subsequently relatively low levels of circulating $\mathrm{PGE}_{1}$, it is conceivable to assume that the in vitro administration of $\mathrm{PGE}_{1}$ bears greater therapeutic efficacy at lower financial burden as compared to systemic $\mathrm{PGE}_{1}$ infusion. Indeed, the in vitro pretreatment of EPC provides the key advantage of avoiding systemic intravenous administration of $\mathrm{PGE}_{1}$ with all its potential pro-inflammatory side effects for the patient rather than enabling the specific targeting of EPC for optimized cell therapy.

We and others have reported that the contribution of progenitor cells to the formation of new vessels involves several crucial steps [18, 19, 33-35]. Homing and transmigration represent the first steps which depend on CXCR4 expression and function [36, 37]. Then, progenitor cells have to undergo endothelial differentiation to physically participate in the formation of new vessels [38]. The present experiments show that $\mathrm{PGE}_{1}$ is capable of enhancing all of these processes. It increases CXCR4 expression and subsequently the transmigratory activity of the progenitor cells. Moreover, $\mathrm{PGE}_{1}$ stimulates expression of genes associated with endothelial differentiation 
including CD31, eNOS and VEGF, suggesting that $\mathrm{PGE}_{1}$ is also capable of enhancing endothelial commitment. Consistently, we observed in vivo a significantly enhanced vascular incorporation of the pretreated cells following hind limb ischemia. Therefore, our data demonstrate that $\mathrm{PGE}_{1}$ provides a multifactorial approach to considerably ameliorate neovascularization capacity of progenitor cells.

As current clinical trials have not yet shown an entirely satisfactory outcome following infusion of progenitor cells $[6,7]$, it appears crucial to develop adequate pretreatment modalities in order to achieve homing of the maximum possible contingent of progenitor cells to the targeted ischemic tissue, and, if possible, even augment their numbers prior to reinfusion. The present study demonstrates that pretreatment of progenitor cells with the $\mathrm{PGE}_{1}$ analogue alprostadil is capable of enhancing the number and functional activity of these cells as well as reducing apoptosis by multimodal treatment ef- fects, and this therefore represents a promising new approach for ex vivo pretreatment of patient-derived progenitor cells. Our results could have major clinical implications as they introduce a feasible, cost-effective and safe pretreatment modality for isolated progenitor cells to enhance their therapeutic potential for autologous cell therapy in patients with acute or chronic cardiovascular diseases.

\section{Acknowledgement}

We appreciate the enthusiastic technical support of Anne Tischer, Michael Eder and Christoph von Hesler. This work was supported by the Deutsche Forschungsgemeinschaft (FOR 501: HE 3044/2-2), the Else Kröner-Fresenius Foundation (A23) and an unrestricted research grant from Schwarz Pharma. This report includes data that were generated during the doctoral thesis of Simon F. Leicht at the Medical School of the Ludwig Maximilian University, Munich, Germany.

\section{References}

1 Hill JM, Zalos G, Halcox JP, et al: Circulating endothelial progenitor cells, vascular function, and cardiovascular risk. $\mathrm{N}$ Engl J Med 2003;348:593-600.

-2 Heeschen C, Lehmann R, Honold J, et al: Profoundly reduced neovascularization capacity of bone marrow mononuclear cells derived from patients with chronic ischemic heart disease. Circulation 2004;109:16151622.

- 3 Vasa M, Fichtlscherer S, Aicher A, et al: Number and migratory activity of circulating endothelial progenitor cells inversely correlate with risk factors for coronary artery disease. Circ Res 2001;89:E1-E7.

-4 Assmus B, Schachinger V, Teupe C, et al: Transplantation of Progenitor Cells and Regeneration Enhancement in Acute Myocardial Infarction (TOPCARE-AMI). Circulation 2002;106:3009-3017.

-5 Strauer BE, Brehm M, Zeus T, et al: Repair of infarcted myocardium by autologous intracoronary mononuclear bone marrow cell transplantation in humans. Circulation 2002;106:1913-1918.

6 Lunde K, Solheim S, Aakhus S, et al: Intracoronary injection of mononuclear bone marrow cells in acute myocardial infarction. N Engl J Med 2006;355:1199-1209.

7 Schachinger V, Erbs S, Elsasser A, et al: Improved clinical outcome after intracoronary administration of bone-marrow-derived progenitor cells in acute myocardial infarction: final 1-year results of the REPAIR-AMI trial. Eur Heart J 2006;27:2775-2783.
8 Coleman RA, Smith WL, Narumiya S: International Union of Pharmacology classification of prostanoid receptors: properties, distribution, and structure of the receptors and their subtypes. Pharmacol Rev 1994;46:205229.

-9 Sugimoto Y, Narumiya S: Prostaglandin E receptors. J Biol Chem 2007;282:11613-11617.

10 Kamiyama M, Pozzi A, Yang L, DeBusk LM, Breyer RM, Lin PC: EP2, a receptor for PGE2, regulates tumor angiogenesis through direct effects on endothelial cell motility and survival. Oncogene 2006;25:7019-7028.

11 Pai R, Szabo IL, Soreghan BA, Atay S, Kawanaka H, Tarnawski AS: PGE(2) stimulates VEGF expression in endothelial cells via ERK2/JNK1 signaling pathways. Biochem Biophys Res Commun 2001;286:923-928.

12 Rao R, Redha R, Macias-Perez I, et al: Prostaglandin E2-EP4 receptor promotes endothelial cell migration via ERK activation and angiogenesis in vivo. J Biol Chem 2007;282: 16959-16968.

13 Salcedo R, Zhang X, Young HA, et al: Angiogenic effects of prostaglandin E2 are mediated by up-regulation of CXCR4 on human microvascular endothelial cells. Blood 2003; 102:1966-1977.

14 Hristovska AM, Rasmussen LE, Hansen PB, et al: Prostaglandin E2 induces vascular relaxation by E-prostanoid 4 receptor-mediated activation of endothelial nitric oxide synthase. Hypertension 2007;50:525-530.
15 Yoder MC, Mead LE, Prater D, et al: Redefining endothelial progenitor cells via clonal analysis and hematopoietic stem/progenitor cell principals. Blood 2007;109:1801-1809.

16 Rossig L, Li H, Fisslthaler B, et al: Inhibitors of histone deacetylation downregulate the expression of endothelial nitric oxide synthase and compromise endothelial cell function in vasorelaxation and angiogenesis. Circ Res 2002;91:837-844.

17 Logan CM, Giordano A, Puca A, Cassone M: Prostaglandin E2: at the crossroads between stem cell development, inflammation and cancer. Cancer Biol Ther 2007;6:1517-1520.

18 Aicher A, Heeschen C, Mildner-Rihm C, et al: Essential role of endothelial nitric oxide synthase for mobilization of stem and progenitor cells. Nat Med 2003;9:1370-1376.

19 Walter DH, Haendeler J, Reinhold J, et al: Impaired CXCR4 signaling contributes to the reduced neovascularization capacity of endothelial progenitor cells from patients with coronary artery disease. Circ Res 2005; 97:1142-1151.

-20 Sasaki K, Heeschen C, Aicher A, et al: Ex vivo pretreatment of bone marrow mononuclear cells with endothelial NO synthase enhancer AVE9488 enhances their functional activity for cell therapy. Proc Natl Acad Sci USA 2006; 103:14537-14541.

21 Wise H, Wong YH, Jones RL: Prostanoid signal integration and cross talk. Neurosignals 2002;11:20-28. 
-22 Alfranca A, Iniguez MA, Fresno M, Redondo JM: Prostanoid signal transduction and gene expression in the endothelium: role in cardiovascular diseases. Cardiovasc Res 2006;70:446-456.

-23 North TE, Goessling W, Walkley CR, et al: Prostaglandin E2 regulates vertebrate haematopoietic stem cell homeostasis. Nature 2007;447:1007-1011.

-24 Lamping K: Endothelial progenitor cells: sowing the seeds for vascular repair. Circ Res 2007; 100:1243-1245.

-25 Faour WH, He Y, He QW, et al: Prostaglan din $\mathrm{E}(2)$ regulates the level and stability of cyclooxygenase- 2 mRNA through activation of p38 mitogen-activated protein kinase in interleukin-1 beta-treated human synovial fibroblasts. J Biol Chem 2001;276:3172031731.

26 Graff J, Skarke C, Klinkhardt U, et al: Effects of selective COX-2 inhibition on prostanoids and platelet physiology in young healthy volunteers. J Thromb Haemost 2007;5:23762385.

-27 Nussmeier NA, Whelton AA, Brown MT, et al: Complications of the COX-2 inhibitors parecoxib and valdecoxib after cardiac surgery. N Engl J Med 2005;352:1081-1091.
28 Kearney PM, Baigent C, Godwin J, Halls H, Emberson JR, Patrono C: Do selective cyclooxygenase- 2 inhibitors and traditional nonsteroidal anti-inflammatory drugs increase the risk of atherothrombosis? Meta-analysis of randomised trials. BMJ 2006;332:13021308 .

29 Boer AK, Drayer AL, Rui H, Vellenga E: Prostaglandin-E2 enhances EPO-mediated STAT5 transcriptional activity by serine phosphorylation of CREB. Blood 2002;100 467-473.

30 Rocca B, Secchiero P, Ciabattoni G, et al: Cyclooxygenase-2 expression is induced during human megakaryopoiesis and characterizes newly formed platelets. Proc Natl Acad Sci USA 2002;99:7634-7639.

31 Feher I, Gidali J: Prostaglandin E2 as stimulator of haemopoietic stem cell proliferation. Nature 1974;247:550-551.

32 Gensch C, Clever Y, Werner C, Hanhoun M, Bohm M, Laufs U: Regulation of endothelial progenitor cells by prostaglandin E1 via inhibition of apoptosis. J Mol Cell Cardio 2007;42:670-677.
33 Chavakis E, Aicher A, Heeschen C, et al: Role of beta2-integrins for homing and neovascularization capacity of endothelial progenitor cells. J Exp Med 2005;201:63-72.

-34 Urbich C, Heeschen C, Aicher A, Dernbach E, Zeiher AM, Dimmeler S: Relevance of monocytic features for neovascularization capacity of circulating endothelial progenitor cells. Circulation 2003;108:2511-2516.

35 Urbich C, Heeschen C, Aicher A, et al: Cathepsin $\mathrm{L}$ is required for endothelial progenitor cell-induced neovascularization. Nat Med 2005;11:206-213.

36 Yamaguchi J, Kusano KF, Masuo O, et al: Stromal cell-derived factor-1 effects on ex vivo expanded endothelial progenitor cell recruitment for ischemic neovascularization. Circulation 2003;107:1322-1328.

37 Ruiz de Almodovar C, Luttun A, Carmeliet P: An SDF-1 trap for myeloid cells stimulates angiogenesis. Cell 2006;124:18-21.

38 Asahara T, Murohara T, Sullivan A, et al: Isolation of putative progenitor endothelial cells for angiogenesis. Science 1997;275:964-967. 